\title{
Analisis Teknis dan Ekonomis Perancangan dan Produksi Pontoon Lift untuk Kapal Ikan 60 GT
}

\author{
Dimas Dwi Hadiansyah dan Triwilaswandio Wuruk Pribadi \\ Jurusan Teknik Perkapalan, Fakultas Teknologi Kelautan, Institut Teknologi Sepuluh Nopember (ITS) \\ Jl. Arief Rahman Hakim, Surabaya 60111 Indonesia \\ e-mail: triwilas.its@gmail.com
}

\begin{abstract}
Abstrak - Pada Studiini dilakukan penelitian terhadap Pontoon yang digunakan sebagai fasilitas utama (docking facility) untuk proses pengedokan maupun peluncuran (ship launching) kapal ikan berukuran 60 GT. Fungsi dari Pontoon sebagai sarana angkat kapal (lift) yang memanfaatkan gaya angkat dari volume zat cair yang dipindahkan dalam ruang Pontoon sehingga dapat disebut Pontoon Lift. Pertama, penelitian diawali dengan melakukan survei ukuran kapal ikan 60 GT daerah Rembang, Tuban, Probolinggo, dan Benoa. Kedua, mendapatkan panjang (L), lebar (B), tinggi ponton (h), dan TLC Pontoon Lift. Ketiga, perhitungan beban kerja untuk penentuan fasilitas produksi. Terakhir, perhitungan estimasi harga produk dan analisis kelayakan investasi industri. Berdasarkan hasil analisis teknis, didapatkan ukuran utama Pontoon Lift adalah $\mathrm{L}=30 \mathrm{~m}, \mathrm{~B}=13,2 \mathrm{~m}, \mathrm{D}=\mathbf{5 , 2 1 9} \mathrm{m}, \mathrm{T}=0,6$ $\mathrm{m}, \mathrm{T}_{\max }=4,219 \mathrm{~m}, \mathrm{~T}_{\text {transfer }}=1,7 \mathrm{~m}$, dan $\mathrm{H}=3,219 \mathrm{~m}$ dengan estimasi biaya produksi sebesar Rp 6,346 miliar. Untuk fasilitas produksi Pontoon Lift dibutuhkan lahan industri seluas $7875 \mathrm{~m}^{2}$ dengan harga investasi industri total sebesar Rp 25,633 yang berlokasi di Jl. Ikan Tuna IV, Kec. Denpasar Selatan, Kel. Pedungan, Pelabuhan Benoa, Bali. Dengan menggunakan metode analisis kelayakan Net Present Value, dan Internal Rate of Return didapatkan hasil Payback Period terjadi pada tahun ke-6 bulan ke-5 setelah terjual sebanyak 15 unit, NPV = Rp 9,908 miliar dan IRR $=15,23 \%$ untuk interest rate (faktor bunga) $=10,25 \%$.
\end{abstract}

Kata Kunci- perancangan, produksi, pontoon lift, sarana pokok galangan, kapal ikan 60 GT

\section{PENDAHULUAN}

$\mathrm{I}^{\mathrm{N}}$ NDUSTRI perkapalan merupakan suatu industri yang menghasilkan suatu keluaran (output) berupa kapal, bangunan lepas pantai atau alat apung lainnya, dan sifat dari industri perkapalan merupakan industri yang berbasis terhadap proyek. Walaupun industri perkapalan memiliki basis terhadap proyek (project based oriented industry), bukan hal yang tidak mungkin bagi suatu galangan untuk dapat mengerjakan proyek reparasi ataupun bangunan baru kapal dalam waktu yang bersamaan. Fasilitas galangan untuk pengedokan maupun peluncuran kapal yang digunakan oleh industri perkapalan sangat tergantung oleh waktu, biaya, dan lahan. Sebagai contoh suatu galangan memiliki sarana slipway untuk peluncuran kapal. Dalam proses pembangunan kapal mulai dari keel laying hingga launching dilakukan pada building berth membutuhkan waktu yang cukup lama sehingga menyebabkan fasilitas slipway galangan tidak dapat beroperasi dan digunakan untuk proyek lainnya. Hal ini menyebabkan potensi lahan dan waktu yang tersedia dari slipway terbuang sia-sia. Selain potensi dari lahan dan waktu yang tersedia, fungsi dari sarana pokok galangan kapal juga menjadi permasalahan. Dengan menggunakan fasilitas seperti slipway, graving dock, dan floating dock fungsi dari sarana pokok tidak dapat digunakan apabila terdapat pekerjaan reparasi atau bangunan baru diatasnya. Kemampuan sarana pokok yang lebih terfokus untuk pengedokan maupun peluncuran kapal dapat meningkatkan kapasitas produksi galangan kapal.

Ketergantungan proses pengerjaan kapal terhadap cuaca maupun iklim tentu menjadi kendala galangan kapal dalam hal produktivitas dan efisiensi jam orang industri perkapalan. Sebagian galangan kapal ikan lain menggunakan slipway sebagai sarana pokok galangan kapal. Banyaknya kapal ikan yang berukuran < 60GT menyebabkan kapasitas galangan kapal ikan untuk memenuhi kebutuhan reparasi tidak tercukupi.

\section{TINJAUAN PUSTAKA}

\section{A. Kapal Ikan di Perairan Indonesia}

Kapal perikanan pada umumnya dapat menggunakan beberapa jenis material seperti baja, kayu, fiber-reinforced plastic (FRP), aluminium, dan ferrocement. Namun, di Indonesia kapal perikanan banyak menggunakan bahan baku kayu. Hal ini dikarenakan oleh karakteristik dari kayu yang mampu bertahan hingga 20 tahun tanpa perlu penggantian lambung (replating) kecuali apabila terdapat kerusakan akibat kecelakaan atau benturan. Kayu masih digunakan sampai saat ini karena banyak ditemukan di Indonesia serta sifat beberapa jenis kayu sesuai dengan persyaratan teknis kapal. Selain itu dari segi harga, material kayu masih relatif terjangkau. Terdapat beberapa jenis kayu yang dapat digunakan dalam pembuatan kapal ikan pada umumnya. Kayu terlebih dahulu diuji kekuatan serta umur pakai (lifetime) pada laboratorium yang telah terdata pada Lembaga Kehutanan. Kayu Meranti, kayu Kulim, kayu Malas, kayu Ulin, kayu Jati, dan kayu Besi merupakan material yang sering digunakan untuk kapal kayu.

Berdasarkan hasil pengamatan lapangan, kapal ikan 60 GT (gross tonnage) di daerah Jawa Timur hampir seluruhnya menggunakan material kayu dan memiliki umur antara 10-30 tahun. Kapal-kapal tersebut dibangun tidak hanya di Jawa tetapi menyebar di seluruh Indonesia seperti Sumatera, Kalimantan, dan Sulawesi. Jumlah kapal ikan dibawah 60 
GT yang beroperasi di Jawa Timur pada tahun 2008-2014 sebanyak lebih dari 600 kapal. Sehingga dengan jumlah dan kondisi tersebut, potensi galangan kapal kayu untuk melakukan pekerjaan reparasi maupun bangunan baru sangat mungkin terjadi.

\section{B. Sarana Pokok Galangan Kapal}

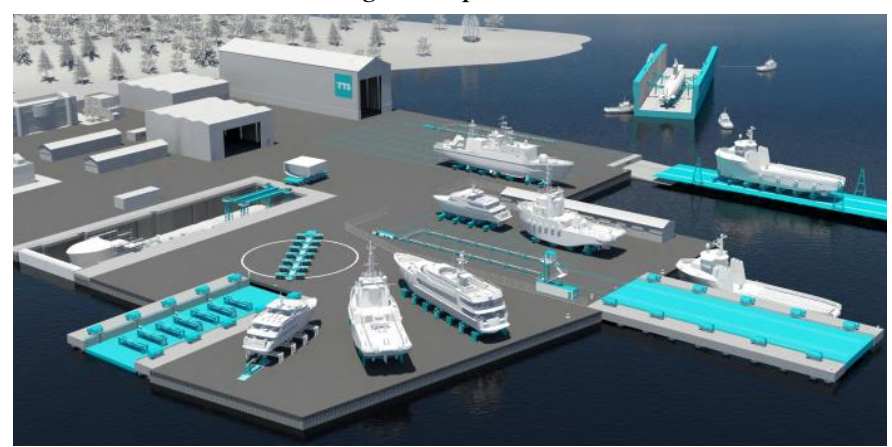

Gambar 1. Sarana pokok galangan kapal Slipway, Graving Dock, Floating Dock, dan Lifting Dock [1]

Sarana pokok galangan pada Gambar 1 merupakan fasilitas yang digunakan untuk memindahkan kapal untuk proses peluncuran maupun pengedokan. Pada dasarnya galangan kapal dibagi menjadi tiga jenis, yaitu building dock shipyard, repair dock shipyard, dan building and repair shipyard. Ketiga jenis galangan tersebut membutuhkan sarana pokok untuk memindahkan kapal dari perairan ke atas dok atau dari atas dok menuju perairan. Berikut adalah 5 jenis sarana pokok galangan yang umum digunakan:

\section{1) Slipway}

Slipway merupakan sarana pokok galangan yang digunakan untuk menaikkan atau meluncurkan kapal dengan menggunakan rel. Slipway terdapat dua jenis, yaitu slipway melintang untuk peluncuran side launching dan slipway memanjang untuk peluncuran end launching. Slipway memiliki sudut kemiringan tertentu yaitu 1/12 hingga 1/24 tergantung kondisi kontur tanah pesisir galangan yang didapat dari survei topografi dan batimetri.

2) Graving Dock

Graving dock atau dok kolam adalah fasilitas pengedokan kapal berbentuk kolam yang telah dikeruk dan dilapisi konstruksi beton dilengkapi dengan pintu kedap air. Ukuran kedalaman, panjang dan lebar dok kolam ditentukan sesuai dengan kapasitas pengedokan.

3) Lifting Dock

Lifting dock merupakan suatu fasilitas pengedokan kapal dengan landasan atau platform yang dapat diangkat (naikturun) secara vertikal dengan mesin pengangkat (hoist). Lifting dock dibagi menjadi dua yaitu Syncrolift dan chain lift kedua sistem ini menggunakan motor listrik dan prinsip katrol untuk menggerakkan kabel atau rantai kemudian platform akan terangkat.

4) Airbag

Teknologi peluncuran menggunakan airbag termasuk teknologi baru dan jarang digunakan galangan kapal modern. Airbag system merupakan metode yang dapat digunakan untuk peluncuran atau pengedokan kapal dengan menggunakan balon karet yang berisi udara.

\section{5) Floating Dock}

Floating dry dock adalah struktur dengan dimensi, kekuatan, displacement, dan stabilitas yang cukup untuk mengangkat kapal dari air dengan menggunakan gaya apung (buoyancy). Tipe dok apung sendiri dapat terdiri dari struktur menerus atau gabungan beberapa segmen ponton.

\section{Pengertian dan Cara Kerja Pontoon Lift}

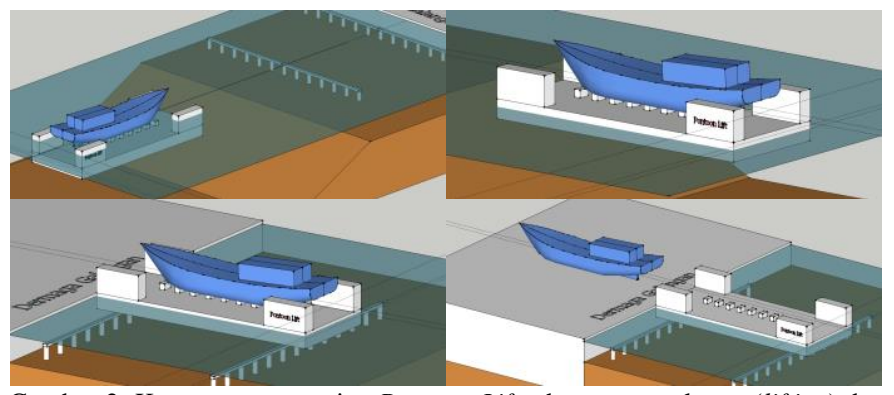

Gambar 2. Konsep pengopeasian Pontoon Lift tahap pengangkatan (lifting) dan tahap pemindahan (transfer)

Pontoon Lift adalah sarana pokok galangan kapal yang memanfaatkan gaya angkat dari volume zat cair yang dipindahkan pada ballast tank ponton sebagai alat untuk mengangkat/menurunkan kapal (lift). Cara kerja pontoon lift terdiri dari dua tahap yaitu tahap pengangkatan (lifting) dan tahap pemindahan (transfer). Berikut adalah penjelasan dari tahap pengangkatan dan tahap pemindahan Gambar 2:

1) Tahap Pengangkatan (Lifting) [2]

- Fase 1 : Ponton berada dalam perendaman penuh tanpa adanya kapal.

- Fase 2: Pengangkatan kapal sebagian, kapal telah terangkat kurang lebih $1 / 2$ dari sarat kapal.

- Fase 3 : Garis sarat tepat diatas balok lunas (keel block).

- Fase 4 : Garis sarat berada tepat sejajar dengan geladak ponton.

- Fase 5 : Ponton berada pada kondisi sarat normal.

2) Tahap Pemindahan (Transfer)

- Kondisi 1 : Kapal telah siap untuk dipindahkan, air balas pada ponton dalam proses pengeluaran.

- Kondisi 2 : Geladak ponton dari pontoon lift sejajar dengan ketinggian building berth, tangki ponton terisi air balas sebagian sesuai dengan posisi tangki agar pontoon lift even keel.

- Kondisi 3 : Kapal telah berada diatas geladak ponton, tangki air balas ponton dikosongkan sehingga siap untuk diluncurkan.

Dimensi dari pontoon lift memiliki karakteristik yang berbeda dengan kapal, penentuan ukuran utama sangat dipertimbangkan oleh dua poin penting. Pertama, syarat dari kondisi bebas dan kapasitas angkat ditentukan oleh lebar maksimum, sarat, panjang keseluruhan dan juga penempatan balok atau panjang yang disangga, berat kapal, dan KG (keel to gravity). Kedua, meliputi syarat dari kekuatan, keselamatan, dan stabilitas dari pontoon lift itu sendiri. 


\section{Tinjauan Perhitungan Ekonomis Pontoon Lift}

Perhitungan ekonomis dilakukan untuk mendapatkan harga estimasi yang digunakan dalam pembangunan pontoon lift dan nilai investasi yang dibutuhkan untuk fasilitas produksi pontoon lift. Investasi pada hakikatnya merupakan penempatan sejumlah dana pada saat ini dengan harapan untuk memperoleh keuntungan dimasa mendatang. Investasi dibagi menjadi dua, yaitu: investasi pada financial assets dan investasi pada real assets. Investasi pada financial assets dilakukan di pasar uang, misalnya berupa sertifikat deposito, commercial paper, surat berharga pasar uang dan lainnya. Atau dilakukan di pasar modal misalnya berupa saham, obligasi, waran, atau opsi. Sedangkan untuk investasi pada real assets berupa pembelian aset produktif, pendirian pabrik, pembukaan pertambangan, pembukaan perkebunan, pembangunan sarana pokok galangan, dan lain-lain.

Proses investasi menunjukkan bagaimana seharusnya seorang investor membuat keputusan investasi pada efek-efek yang bisa dipasarkan dan kapan dilakukan. Untuk itu diperlukan 5 tahapan sebagai berikut [3]:

1) Menentukan tujuan investasi. Terdiri dari tingkat pengembalian yang diharapkan (expected rate of return), tingkat resiko (rate of risk) dan ketersediaan jumlah dana yang akan diinvestasikan.

2) Melakukan analisis atau melakukan pendekatan fundamental dan pendekatan teknis.

3) Melakukan pembentukan portofolio. Dilakukan identifikasi terhadap tingkat resiko akibat investasi yang dilakukan, kemudian dilakukan penurunan tingkat resiko.

4) Melakukan evaluasi kinerja portofolio. Terdiri dari measurement yaitu penilaian atas dasar aset dengan menggunakan rate of return dan comparison yaitu penilaian atas dasar perbandingan antara dua set portofolio yang memiliki resiko serupa.

5) Melakukan revisi kinerja portofolio. Tindak lanjut dari tahap evaluasi kinerja portofolio, dari tahap inilah selanjutnya dilakukan revisi terhadap resiko yang terjadi untuk mendapatkan nilai investasi yang lebih menguntungkan.

Pada penelitian mengenai pontoon lift dilakukan perhitungan ekonomis meliputi estimasi harga produksi atau harga jual pontoon lift dan analisis kelayakan investasi industri pontoon lift dengan menggunakan metode pengujian kelayakan investasi:

1) Break Even Point (BEP)

2) Pay Back Period (PBP)

3) Net Present Value (NPV)

4) Internal Rate of Return (IRR)

Perhitungan estimasi harga produksi atau harga jual pontoon lift menggunakan pendekatan harga conceptual or screening estimate (estimate class 5) [4] yang dibuat berdasarkan data proyek yang telah dibuat di waktu lalu atau dengan parametric model, judgement, dan analogy. Digunakan pada tingkat penyelesaian proyek $0 \% \mathrm{~s} / \mathrm{d} 2 \%$ dan memiliki tingkat akurasi batas bawah $-20 \%$ s/d $-50 \%$ dan batas atas $+30 \%$ s/d $+100 \%$. Sedangkan analisis kelayakan investasi dilakukan dengan penentuan lokasi industri dengan metode analitycal hierarchy process (AHP), perhitungan jumlah mesin dan peralatan, dan biaya operasional dan perawatan industri pontoon lift.

\section{METODOLOGI PENELITIAN}

\section{A. Diagram Alir}

Adapun proses yang dilakukan pada penelitian pontoon lift dapat dilihat pada Gambar 3.

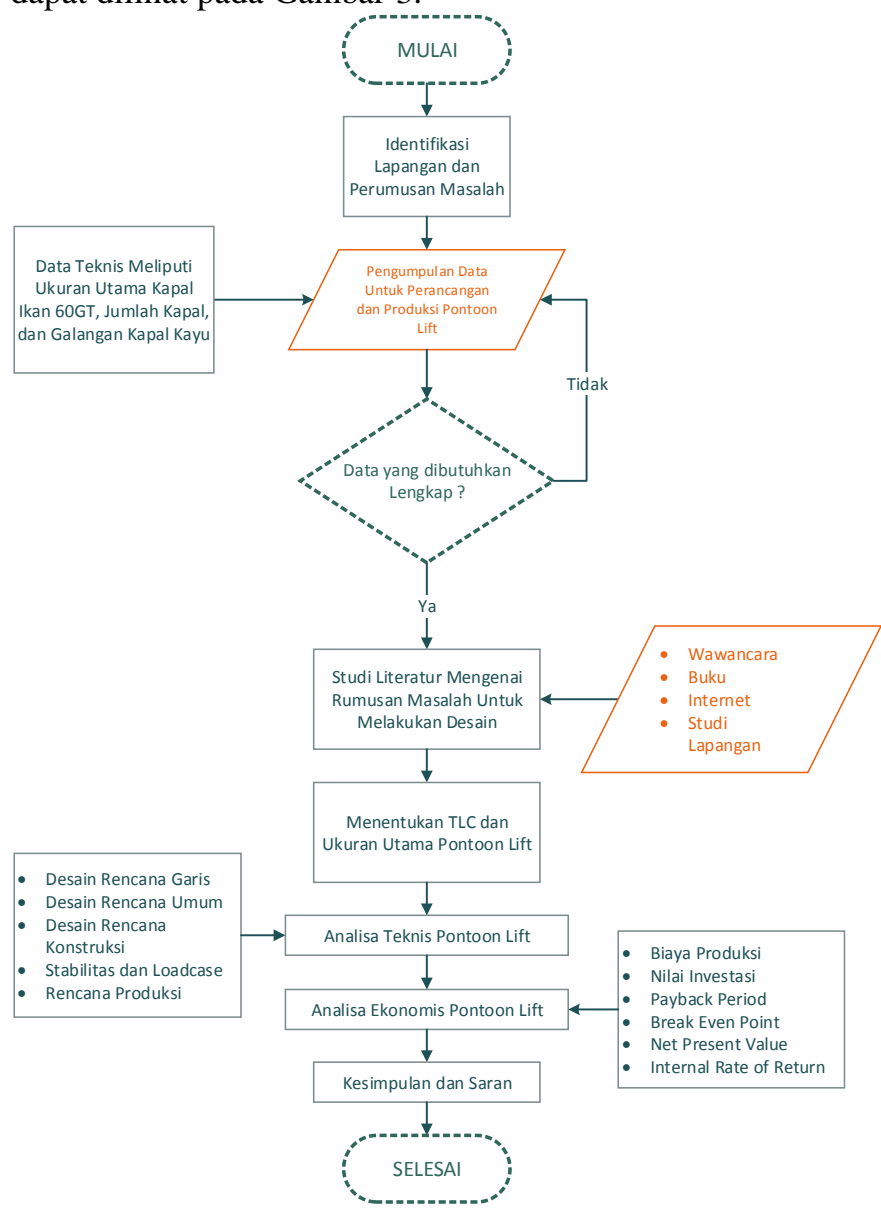

Gambar 3. Diagram alir pengerjaan Studi“Analisis Teknis dan Ekonomis Perancangan dan Produksi Pontoon Lift untuk Kapal Ikan 60 GT"

\section{B. Tahap Pengumpulan Data}

Tahap ini memiliki tujuan untuk mendapatkan data primer dan/atau data sekunder yang berkaitan dengan masalah atau kondisi pada penelitian tersebut. Dalam penelitian ini, data yang digunakan merupakan data primer dan sekunder.

\section{Analisis dan Pengolahan Data}

Setelah data-data tersebut terkumpul, data kemudian dianalisis dengan proses pembelajaran pada literatur-literatur yang berkaitan, kemudian dilakukan analisis dan pengolahan data dalam bentuk bahasa engineering yang semestinya sehingga menghasilkan output berupa design statement. Design statement yaitu TLC, ukuran utama Pontoon Lift, dan batasan-batasan desain. 


\section{Penentuan Ton Lifting Capacity (TLC) dan Ukuran Utama Pontoon Lift}

Pendekatan perhitungan berat kapal ikan didapatkan dengan menggunakan rumus dari displacement kapal yang telah beroperasi daerah Tanjung Benoa Bali. Selain itu untuk ukuran utama pontoon lift dilakukan pengukuran langsung (L, B, H, T) pada kapal ikan 60 GT.

\section{E. Tahap Analisis Teknis}

Pada tahap ini dilakukan pembuatan model dan konsep pontoon lift yang diikuti dengan desain rencana garis, rencana umum, rencana konstruksi, dan rencana produksi. Selain itu pada tahap ini dilakukan perhitungan teknis seperti konstruksi dan kekuatan, stabilitas, kondisi pembebanan, dan beban kerja pada tahap produksi, dan penentuan lokasi industri.

\section{F. Tahap Analisis Ekonomis}

Proses selanjutnya yaitu perhitungan estimasi harga jual atau harga produksi pontoon lift kemudian analisis kelayakan investasi untuk fasilitas produksi dan industri pontoon lift.

\section{G. Kesimpulan}

Pada tahap ini dilakukan penarikan kesimpulan dari hasil analisis, perhitungan, dan penilaian baik dalam hal teknis maupun ekonomis.

\section{PERANCANGAN DAN PRODUKSI PONTOON LIFT}

\section{A. Skenario Pengoperasian Pontoon Lift}

Pengoperasian pontoon lift pada Gambar 2 dibagi menjadi

5 tahapan berikut ini:

1) Pontoon lift ditarik oleh kapal menuju perairan yang lebih dalam dengan kondisi tangki air balas kosong, keel block dan side block diatur sesuai dengan docking plan.

2) Pada perairan yang telah ditentukan tangki-tangki air balas pontoon lift diisi sampai dengan kondisi sarat maksimum untuk memulai proses pengangkatan kapal yang akan docking.

3) Kapal yang telah berada pada posisi pengangkatan (lifting position) ditambatkan pada sidewall pontoon lift kemudian air balas dikeluarkan dan memasuki tahap pengangkatan fase 1 sampai 5 .

4) Setelah berada pada kondisi tahap pengangkatan fase 5 , pontoon lift kemudian ditarik menuju dermaga galangan untuk memulai tahap pemindahan kapal (transfer).

5) Tangki-tangki air balas diisi kembali untuk menempatkan pontoon lift diatas balok penahan dalam kondisi railway ponton lurus dengan railway pada dermaga, kemudian proses pemindahan kapal dilakukan.

\section{B. Analisis Teknis Perancangan Pontoon Lift}

Perancangan pontoon lift dapat dilakukan melalui proses analisis dan perhitungan meliputi berat dan distribusi berat kosong kapal ikan 60 GT. Setelah itu dilakukan perhitungan TLC dan ukuran utama, desain rencana garis, rencana umum, perhitungan konstruksi dan kekuatan, desain rencana konstruksi, distribusi berat, momen lengkung (bending moment), perhitungan kekuatan memanjang, dan analisis stabilitas pontoon lift.

$$
\Delta=L \cdot B \cdot T \cdot C_{b} \cdot \rho
$$

Dimana:

$\Delta=$ Displacement $\mathrm{kapal}$ (ton)

$\mathrm{L} \quad=$ Panjang kapal $(\mathrm{m})$

$\mathrm{B}=$ Lebar kapal (m)

$\mathrm{T}$ = Saratkapal (m)

$\mathrm{C}_{\mathrm{b}} \quad=$ Koefisien blok kapal

$\rho=$ Massa jenis air laut $\left(1,025 \mathrm{ton} / \mathrm{m}^{3}\right)$

Persamaan (1) digunakan untuk mendapatkan nilai displacement kapal ikan dan pontoon lift selama perhitungan analisis teknis dilakukan. Apabila nilai displacement $(\nabla$ satuan $\mathrm{m}^{3}$ ) maka nilai tersebut belum dikalikan oleh massa jenis zat cair yang artinya volume displacement. Oleh karena itu nilai displacement ( $\Delta$ satuan ton) akan berubah setelah dikalikan oleh massa jenis zat cair yang berarti berat displacement, dalam hal ini kapal sangat umum berada pada zat cair air tawar atau air laut. Untuk mendapatkan nilai displacement dan $\mathrm{C}_{\mathrm{b}}$ kapal ikan maka dilakukan pengukuran terhadap kapal ikan yang terdapat di lapangan. Data pada Tabel 1 didapatkan melalui observasi lapangan pada daerah pesisir utara Jawa Timur meliputi Rembang, Tuban, Probolinggo, dan Pelabuhan Benoa Bali.

Tabel 1.

Data ukuran utama kapal ikan 30 - 90 GT ( $\pm 50 \% 60$ GT)

\begin{tabular}{llccccc}
\hline \hline No. & \multicolumn{1}{c}{ Nama Kapal } & $\begin{array}{c}\mathrm{L} \\
(\mathrm{m})\end{array}$ & $\begin{array}{c}\mathrm{B} \\
(\mathrm{m})\end{array}$ & $\begin{array}{c}\mathrm{H} \\
(\mathrm{m})\end{array}$ & $\begin{array}{c}\mathrm{T} \\
(\mathrm{m})\end{array}$ & $\mathrm{GT}$ \\
\hline 1. & KM. Setia Sentosa Makmur & 12,0 & 5,0 & 3,0 & 1,4 & 29 \\
2. & KM. Berkat Rahmat & 20,1 & 5,24 & 4,05 & 1,5 & 39 \\
3. & KM. Putra Mahera & 14,2 & 6,6 & 4,5 & 1,3 & 39 \\
4. & KM. Primus Jaya 8 & 24,2 & 5,8 & 2,7 & 1,7 & 58 \\
5. & KM. Perintis Jaya 19 & 24,1 & 5 & 2,1 & 1,5 & 58 \\
6. & KM. Alamprima & 23,4 & 5,2 & 2,2 & 1,6 & 60 \\
7. & KM. Bandar Nelayan & 24,3 & 5,2 & 2,2 & 1,6 & 60 \\
8. & KM. Bintangmas Diamond & 24,5 & 5,3 & 2,3 & 1,7 & 63 \\
9. & KM. Primus Jaya & 26,3 & 6 & 3,1 & 1,8 & 86 \\
10. & KM. Putra Leo Agung & 26,1 & 5,9 & 2,9 & 1,8 & 88 \\
\hline \hline
\end{tabular}

GT - Gross Tonnage

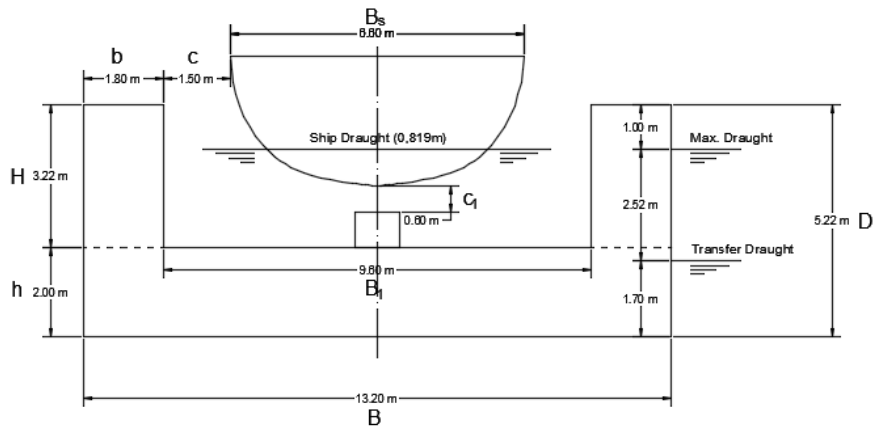

Gambar 4. Ukuran utama pontoon lift untuk kapal ikan 60 GT dengan clearance sisi kapal 1,5 meter dan alas 0,6 meter.

TLC atau ton lifting capacity adalah displacement (satuan ton) dari kapal terberat yang dapat diangkat oleh dok dalam 
keadaan normal service [5]. Didapatkan dari hasil perhitungan displacement pontoon lift pada sarat kosong $(\mathrm{T}=1,0 \mathrm{~m})$ adalah sebesar 405,9 ton dengan berat kosong 200,44 ton, sehingga TLC didapatkan kurang lebih sebesar 205 ton. Selain itu didapatkan ukuran utama pontoon lift Gambar 4 berdasarkan ukuran kapal ikan terbesar pada Tabel 1 adalah sebagai berikut:

$\mathrm{L}=30,0 \quad \mathrm{~m}$ (panjang keseluruhan)

$\mathrm{h} \quad=2,0 \quad \mathrm{~m}$ (jarak antara bottom dan geladak ponton)

$\mathrm{b} \quad=1,8 \quad \mathrm{~m}$ (lebar sidewalls)

$\mathrm{H}=3,219 \mathrm{~m}$ (jarak antara geladak ponton dan geladak sidewalls)

$\mathrm{B}_{1}=9,6 \quad \mathrm{~m}$ (lebar geladak pengedokan)

$\mathrm{D}=5,219 \mathrm{~m}$ (tinggi keseluruhan)

$\mathrm{B}=13,2 \mathrm{~m}$ (lebar keseluruhan)

Tahap selanjutnya adalah perhitungan konstruksi, berat dan kekuatan memanjang pontoon lift. Sistem konstruksi yang digunakan ponton adalah sistem konstruksi campuran dimana konstruksi melintang digunakan pada sisi, dan konstruksi memanjang digunakan pada geladak dan alas. Untuk perhitungan berat dapat dilihat pada Gambar 5 dan Tabel 2.

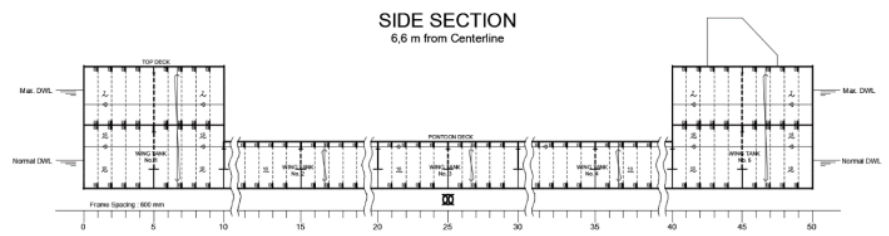

Gambar 5. Pembagian blok pontoon lift untuk perhitungan berat konstruksi metode pos per pos.

Dalam memperhitungkan berat terdapat beberapa pendekatan yaitu dengan menggunakan rumus pada literatur atau dengan menggunakan perhitungan berat pos per pos. Karena ukuran dan bentuk dari pontoon lift yang tidak cukup besar, maka perhitungan berat pos per pos Gambar 5 dapat menghasilkan pendekatan yang cukup akurat Tabel 2.

Tabel 2.

Hasil perhitungan berat konstruksi pontoon lift pos per pos

\begin{tabular}{ccccc}
\hline \hline \multicolumn{5}{c}{ Hasil perhitungan berat konstruksi pontoon lift pos per pos } \\
\hline No. & Nomor Gading & $\begin{array}{c}\text { Panjang } \\
\text { Blok (mm) }\end{array}$ & Volume (m) & Berat (ton) \\
\hline 1. & $0-10$ & 6300 & 5,4420 & 42,720 \\
2. & $10-20$ & 5400 & 3,0018 & 23,564 \\
3. & $20-30$ & 6600 & 4,1789 & 32,804 \\
4. & $30-40$ & 5400 & 3,0018 & 23,564 \\
5. & $40-50$ & 6300 & 5,4420 & 42,720 \\
\hline \hline
\end{tabular}

Perhitungan kekuatan memanjang ponton dilakukan setelah mendapatkan hasil distribusi berat dan momen. Distribusi berat dan momen pada pontoon lift dibagi menjadi 4 komponen sebagai berikut:

1) Distribusi gaya tekan $w(x)$ konstruksi

2) Distribusi gaya apung $b(x)$ pontoon lift

3) Distribusi gaya tekan w(x) air balas

4) Distribusi gaya tekan $\mathrm{w}(\mathrm{x})$ kapal diatas pontoon lift

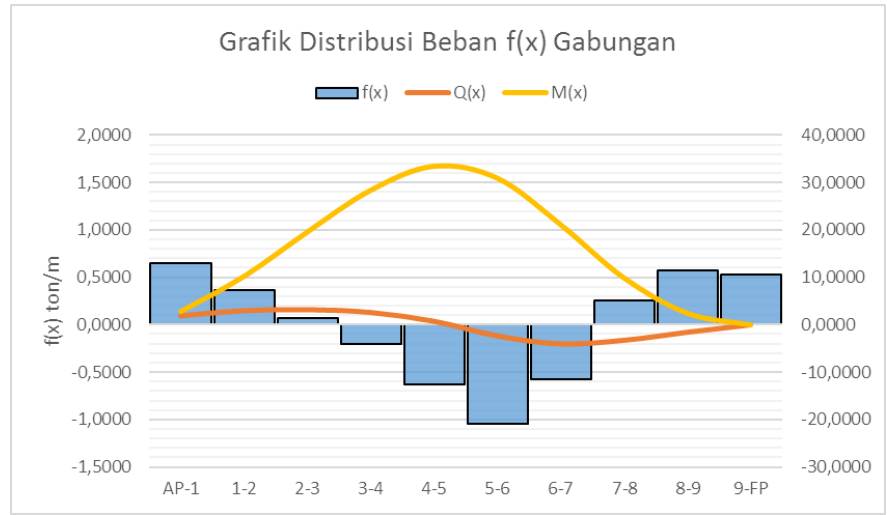

Gambar 6. Grafik distribusi beban $\mathrm{f}(\mathrm{x})$, gaya lintang $\mathrm{Q}(\mathrm{x})$ dan momen $\mathrm{M}(\mathrm{x})$ gabungan pontoon lift dan kapal ikan.

Sehingga setelah mendapatkan hasil perhitungan komponen-komponen diatas, dapat dilakukan perhitungan distribusi beban gabungan kemudian perhitungan gaya lintang dan momen Gambar 6. Perhitungan distribusi berat dilakukan dengan menggunakan Excel spreadsheet dalam bentuk tabel sehingga dapat lebih mudah untuk dilakukan perhitungan.

Perhitungan kekuatan memanjang pontoon lift dibutuhkan karena konstruksi konstruksi yang digunakan adalah konstruksi campuran dan pengoperasioan pontoon lift yang sangat memungkinkan untuk mengalami tegangan akbiat bending. Terdapat 4 kondisi momen bending pada kekuatan memanjang Tabel 3 yang harus terpenuhi oleh pontoon lift, yaitu:

1) Tegangan pada geladak dan alas kondisi Hogging

2) Tegangan pada geladak dan alas kondisi Sagging

3) Tegangan pada geladak dan alas kondisi Air Tenang

4) Tegangan pada geladak dan alas kondisi Transfer

Tabel 3.

Pengecekan status kekuatan memanjang pontoon lift

\begin{tabular}{ccccccc}
\hline \hline Kriteria & Batasan & Satuan & Hogging & Sagging & $\begin{array}{c}\text { Air } \\
\text { Tenang }\end{array}$ & Transfer \\
\hline$\sigma_{\text {deck }}$ & 1032,91 & $\mathrm{~kg} / \mathrm{cm}^{2}$ & 157,18 & 154,89 & 11,86 & 72,80 \\
$\sigma_{\text {bottom }}$ & 1032,91 & $\mathrm{~kg} / \mathrm{cm}^{2}$ & 138,61 & 136,59 & 10,46 & 65,20 \\
$\mathrm{~W}_{\text {total }}$ & 47.840 & $\mathrm{~cm}^{3}$ & & $150.996,57$ & \\
$\mathrm{~W}_{\text {deck }}$ & 47.840 & $\mathrm{~cm}^{3}$ & & $284.100,45$ & \\
$\mathrm{~W}_{\text {bottom }}$ & 47.840 & $\mathrm{~cm}^{3}$ & & $322.154,44$ & \\
Momen & $4,3 \times 10^{6}$ & $\mathrm{~cm}^{4}$ & & $30,2 \times 10^{6}$ & \\
Inersia & & & & & \\
& Status & & & & \\
\hline \hline
\end{tabular}

Tahap berikutnya adalah pengecekan stabilitas pontoon lift Tabel 4. Adapun kondisi (loadcase) yang digunakan untuk pengecekan stabilitas adalah:

1) Kondisi 1 : Pontoon lift berada pada sarat penuh (full submergence)

2) Kondisi 2 : Pontoon lift mengangkat sebagian kapal kurang lebih $1 / 2$ sarat kapal docking

3) Kondisi 3 : Garis waterline berada tepat diatas keel block

4) Kondisi 4 : Garis waterline berada pada geladak ponton

5) Kondisi 5 : Pontoon lift berada pada Sarat Normal 
Selain itu kriteria yang berlaku terhadap seluruh kondisi 1 sampai dengan 5 tersebut adalah [6] [7]:

1) Minimum GM tidak boleh kurang dari $1,0 \mathrm{~m}$

2) Area 0 - 30 atau GZ maks. tidak boleh kurang dari hasil analisis

3) Angle of vanishing stability $\mathrm{L} \leq 100 \mathrm{~m}$ harus lebih dari $20^{\circ}$

Tabel 4.

Hasil analisis stabilitas pontoon lift pada 5 kondisi (loadcase)

\begin{tabular}{cccccccc}
\hline \multirow{2}{*}{ Kriteria } & Batasan & Satuan & \multicolumn{6}{c}{ Kondisi } \\
\cline { 4 - 8 } & & & 1 & 2 & 3 & 4 & 5 \\
\hline T & - & $\mathrm{m}$ & 4,220 & 3,807 & 2,789 & 2,000 & 1,000 \\
KG & - & $\mathrm{m}$ & 1,633 & 1,791 & 1,803 & 1,822 & 2,754 \\
GM & 1,0 & $\mathrm{~m}$ & 1,149 & 1,068 & 1,742 & 1,903 & 12,26 \\
GZ Max & 3,1513 & $\mathrm{~m} . \mathrm{deg}$ & 3,776 & 4,019 & 8,403 & 12,87 & 60,49 \\
Angle of & 20 & $\mathrm{deg}$ & 36,2 & 34,6 & 50,3 & 58,8 & 72,4 \\
Vanish & & & & & & & \\
& Status & & Pass & Pass & Pass & Pass & Pass \\
\hline \hline
\end{tabular}

C. Analisis Teknis Produksi Pontoon Lift

Tahap awal dalam melakukan analisis teknis produksi pontoon lift adalah dengan menentukan work breakdown structure (WBS) dan beban ( $\mathrm{kg} / \mathrm{hari}$ ) yang dapat dibuat dalam bentuk WBS level ataupun seperti pada Tabel 5. Kemudian dilanjutkan dengan pemilihan lokasi industri untuk penempatan fasilitas produksi dan perencanaan layout industri pontoon lift.

Tabel 5.

Work breakdown structure pada proses produksi pontoon lift

\begin{tabular}{ccccc}
\hline \hline Level & Breakdown Structure & $\begin{array}{c}\text { Duration } \\
\text { (days) }\end{array}$ & Berat (ton) & $\begin{array}{c}\text { Beban } \\
\text { (kg/hari) }\end{array}$ \\
\hline 0 & Pontoon Lift & 100 & 200,439 & 2004,395 \\
1 & Pontoon Block & 80 & 170,502 & 2131,280 \\
1.1 & Bottom Panel & 32 & 67,655 & 2114,214 \\
1.2 & Deck Panel & 20 & 42,132 & 2106,596 \\
2 & Sidewall Block & 20 & 29,937 & 1496,856 \\
\hline \hline
\end{tabular}

\section{Analisis Ekonomis}

Perhitungan analisis ekonomis diawali dengan estimasi harga pontoon lift yang dapat digunakan sebagai harga jual untuk menghasilkan pendapatan bagi industri pontoon lift. Dari hasil perhitungan estimasi menggunakan metode estimate class 5 didapatkan harga jual pontoon lift adalah sebesar Rp 6.345.858.814,29. Dimana harga tersebut terdiri dari dua komponen utama yaitu:

1) Harga utuh pontoon lift

Meliputi harga dari hull part, machinery part, dan electric part (bahan pokok dan material utama).

2) Nilai estimasi laba

Meliputi harga dari proses konstruksi, inspeksi, indirect cost, dan margin (pendapatan bersih industri).

Sehingga didapatkan harga utuh pontoon lift adalah sebesar Rp 3.620.393.810,71 dan nilai estimasi laba sebesar Rp 2.644.107.839,29. Setelah mendapatkan nilai harga tersebut langkah selanjutnya adalah menguji kelayakan investasi dari industri pontoon lift. Pada penelitian kali ini pengujian kelayakan investasi dibatasi oleh bunga bank sebesar $10,25 \%$, asumsi tanpa ada kendala pada keuangan galangan dengan umur ekonomis industri selama 25 tahun. Target penjualan pontoon lift per tahun adalah sebanyak 3 pontoon lift yang disesuaikan dengan lama proses produksi selama 100 hari kerja untuk satu pontoon lift.

Total biaya investasi yang dibutuhkan industri pontoon lift diperoleh sebesar Rp 25.632.496.307,31 dimana modal yang digunakan sebanyak $70 \%$ pinjaman bank. Masa pinjaman bank selama 10 tahun dan dibutuhkan dana pembayaran angsuran ditambah bunga sebanyak $\mathrm{Rp} 2.951 .533 .571$ setiap tahun.

\begin{tabular}{ccc}
\multicolumn{3}{c}{ Tabel 6. } \\
Rekapitulasi analisis kelayakan investasi pontoon lift dengan & 70\% modal pinjaman bank \\
\hline \hline No. & \multicolumn{1}{c}{ Parameter } & Value \\
& Modal Awal: 30\% & Modal Sendiri, 70\% Modal Bank \\
\hline 1. & Break Even Point & 15 Unit \\
2. & Payback Period & Tahun ke-6 Bulan ke-7 \\
3. & Net Present Value & Rp $9.907 .573 .412,72$ \\
4. & Internal Rate of Return & $15,23 \%(10,25 \%)$ \\
\hline \hline
\end{tabular}

\section{KESIMPULAN}

Berdasarkan hasil perhitungan dan analisis yang telah dilakukan, maka dapat disimpulkan:

1) Berdasarkan ukuran utama kapal ikan 60 GT, pertimbangan pasang surut/naik, dan clearance didapatkan ukuran utama dan TLC pontoon lift sebagai berikut:

- Jenis : Pontoon Lift 60 TLC

- $\mathrm{L}=30,00 \mathrm{~m} \quad \mathrm{~T}_{\max }=4,22 \mathrm{~m}$

- $\mathrm{B}=13,20 \mathrm{~m} \quad \mathrm{~T}_{\text {kapal } \max }=0,90 \mathrm{~m}$

- $\mathrm{D}=5,22 \mathrm{~m} \quad \mathrm{~T}_{\text {kosong }}=0,60 \mathrm{~m}$

- $\mathrm{H}=3,22 \mathrm{~m} \quad \mathrm{~T}_{\text {transfer }}=1,70 \mathrm{~m}$

2) Untuk dapat mengoperasikan pontoon lift dibutuhkan kedalaman laut minimum sebesar $0,74 \mathrm{~m}$ pada pasang surut terendah. Posisi geladak ponton dan dermaga harus sejajar tanpa ada jarak dan posisi penyangga (girder) ponton tepat pada wrang pelat pontoon lift. Kekuatan memanjang dengan batas sebesar 101,2941 MPa terpenuhi dengan nilai tegangan terbesar $\sigma_{\text {deck }}=157,1812$ $\mathrm{kg} / \mathrm{cm}^{2}$ atau $15,4142 \mathrm{MPa}$. Stabilitas pontoon lift untuk kriteria $\mathrm{GM} \geq 1,0 \mathrm{~m}$ terpenuhi dimana GM terkecil terjadi ketika kondisi lifting phase 2 dengan $\mathrm{GM}=1,068 \mathrm{~m}$.

3) Sarana pendukung yang dibutuhkan galangan pengguna pontoon lift yaitu keel block, side block, lori (cradle), sling (wire rope), winch, dan balok (girder) penyangga pontoon lift.

4) Harga estimasi pontoon lift (harga jual) didapatkan

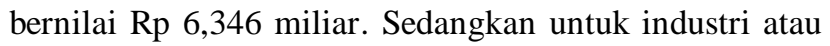
fasilitas produksi, biaya investasi yang dibutuhkan adalah Rp 25,633 miliar dan dibutuhkan tanah seluas $7875 \mathrm{~m}^{2}$. Dengan umur ekonomis industri selama 25 tahun, bobot modal awal yang dibutuhkan untuk mendapatkan kelayakan investasi adalah $30 \%$ modal sendiri dan $70 \%$ modal bank. Dimana payback period terjadi pada tahun 
ke- 6 bulan ke-5, dengan nilai BEP $=15$ unit, NPV $=$ Rp 9,908 miliar dan IRR $=15,23 \%$ untuk interest rate $(I R)=$ $10,25 \%$ dengan kesimpulan IRR > interest rate, investasi layak/dapat dipertimbangkan.

\section{DAFTAR PUSTAKA}

[1] S. Maksjuta, "TTS Syncrolift Fast Docking Systems," TTS Group, Norway (2016, Sept.).

[2] R. Heger, Dockmaster Training Manual, Heger Dry Dock Inc., Holliston, U.S. (2005, June).

[3] S. Widjaja, Manajemen Produksi untuk Industri Perkapalan, Institut Teknologi Sepuluh Nopember, Surabaya, Indonesia (1996, Jan.).

[4] Estimasi Harga Pembangunan Kapal Baru, PERTAMINA, Jakarta, Indonesia (2007).

[5] Rules and Regulations for the Construction and Classification of Floating Docks, Lloyd's Register, London, EC3M 4BS U.K. (2016) Pt. 2 Ch. 1 Sec. 221.

[6] "Rules for Floating Docks," Rules for the Classification and Construction of Seagoing Steel Ships, Biro Klasifikasi Indonesia, Jakarta, Indonesia (2002) Sec. 3 3-1.

[7] Intact Stability Code, IMO Standard (1974). 